\title{
Endocrine regulation of airway contractility is overlooked
}

\section{Ynuk Bossé}

Institut Universitaire de Cardiologie et de Pneumologie de Québec, Université Laval, Québec, Québec, Canada G1V 4G5
Correspondence should be addressed

to $Y$ Bossé

Email

ynuk.bosse@criucpq.ulaval.ca

\begin{abstract}
Asthma is a prevalent respiratory disorder triggered by a variety of inhaled environmental factors, such as allergens, viruses, and pollutants. Asthma is characterized by an elevated activation of the smooth muscle surrounding the airways, as well as a propensity of the airways to narrow excessively in response to a spasmogen (i.e. contractile agonist), a feature called airway hyperresponsiveness. The level of airway smooth muscle (ASM) activation is putatively controlled by mediators released in its vicinity. In asthma, many mediators that affect ASM contractility originate from inflammatory cells that are mobilized into the airways, such as eosinophils. However, mounting evidence indicates that mediators released by remote organs can also influence the level of activation of ASM, as well as its level of responsiveness to spasmogens and relaxant agonists. These remote mediators are transported through circulating blood to act either directly on ASM or indirectly via the nervous system by tuning the level of cholinergic activation of ASM. Indeed, mediators generated from diverse organs, including the adrenals, pancreas, adipose tissue, gonads, heart, intestines, and stomach, affect the contractility of ASM. Together, these results suggest that, apart from a paracrine mode of regulation, ASM is subjected to an endocrine mode of regulation. The results also imply that defects in organs other than the lungs can contribute to asthma symptoms and severity. In this review, I suggest that the endocrine mode of regulation of ASM contractility is overlooked.
\end{abstract}
Key Words
- asthma
- airway smooth muscle
- airway hyperresponsiveness
- contractility
- spasmogens
- bronchodilators

Journal of Endocrinology (2014) 222, R61-R73

\section{Introduction}

Asthma is a prevalent and debilitating lung disorder (Masoli et al. 2004, Haselkorn et al. 2010). The symptoms of asthma are driven by multifarious inflammations that are triggered in susceptible individuals by exposure to a diverse variety of environmental factors, such as allergens, viruses, and pollutants. The most distinctive feature of asthma is intermittent airflow obstruction. The waxing and waning nature of asthma symptoms is due to recurrent inflammatory flares. These flares occur upon inhalation of the liable environmental factors and each leads to transient constriction of the airways. The smooth muscle embedded within the airway wall, hereafter called airway smooth muscle
(ASM), is the motor driving airway constriction. Indeed, ASM is arranged nearly circumferentially within the airway wall and strives to shorten once stimulated to contract. Consequently, ASM shortening converges the airway wall within the lumen and, by doing so, provokes respiratory distress by impeding the flow of air into the lung.

\section{ASM activation and airway responsiveness in asthma}

The amount of shortening that ASM undergoes and the concomitant degree of airway constriction achieved

Published by Bioscientifica Ltd. 
depend on the force generated by ASM. In turn, the force is mainly dictated by the level of activation of ASM, which is determined by a balance between endogenous spasmogens (i.e. contractile agonists) and bronchodilators (Fig. 1). The level of ASM activation is difficult to appraise in vivo. One strategy is to measure the change in lung function evoked by the inhalation of drugs that relax ASM (i.e. exogenous bronchodilators). In asthma, exogenous bronchodilators substantially improve lung function. In fact, a $>12 \%$ reversal of airway obstruction pre- vs post-bronchodilators is the most objective criterion used to diagnose asthma according to current guidelines (National Heart Lung and Blood Institute National Asthma Education and Prevention Program 2007,
Bateman et al. 2008). The greater responsiveness to bronchodilators represents a solid evidence that ASM activation is elevated in asthma.

Apart from being putatively overactivated, the airways of asthmatic individuals also respond excessively to a bronchoprovocative challenge with a spasmogen (Crapo et al. 2000). This typical feature of asthma is called airway hyperresponsiveness (AHR). Representative curves that describe the level of airway responsiveness in asthmatic and non-asthmatic individuals are illustrated in Fig. 2. However, it is important to understand that AHR does not necessarily imply that ASM is hypercontractile, as many other factors found in vivo can act additively and synergistically with ASM contraction to increase the

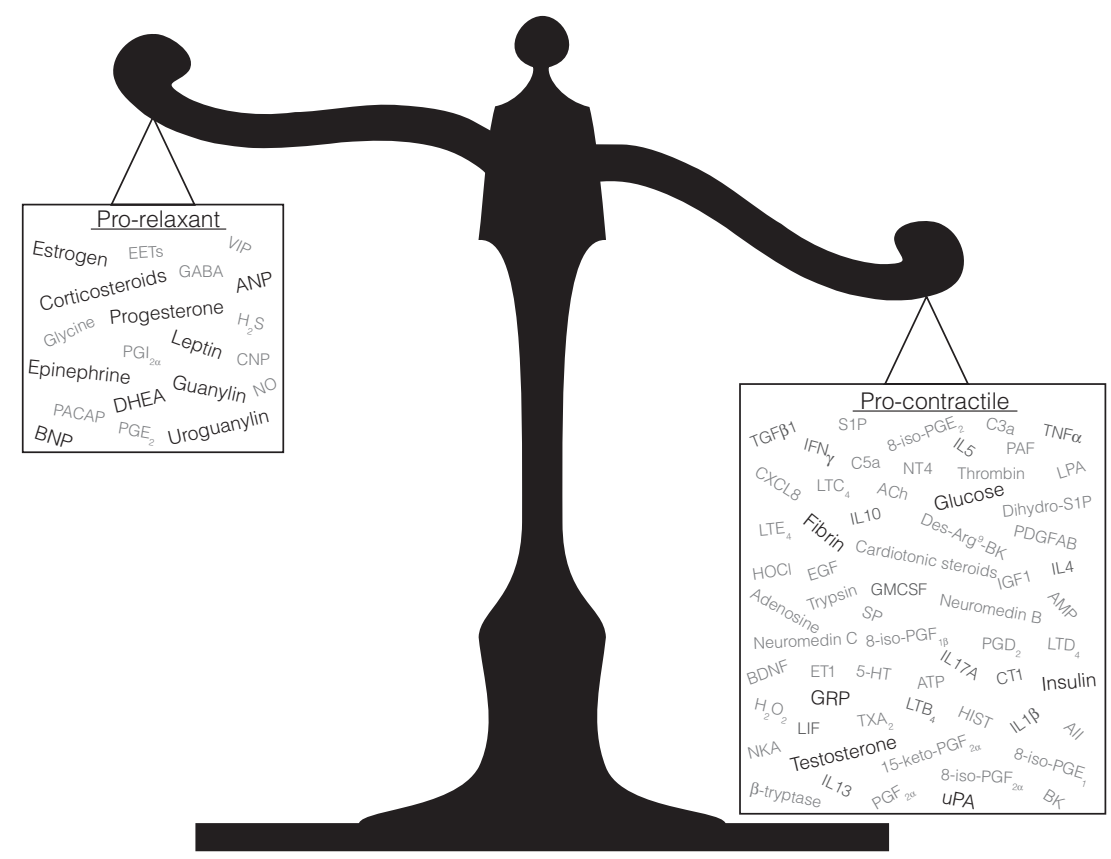

Figure 1

The level of activation of airway smooth muscle (ASM) is controlled by a balance between spasmogens and bronchodilators. Airway contractility is further affected by other types of mediators that influence the responsiveness of ASM to either spasmogens or bronchodilators. Excessive airway constriction in asthma can thus be a consequence of the following: i) a greater expression of spasmogens; ii) a decreased expression of bronchodilators; iii) an altered expression of mediators affecting ASM responsiveness to spasmogens and bronchodilators; or iv) expression of a mixture of any of these elements. Owing to the variable nature of airway obstruction and the well-recognized heterogeneity of asthma pathogenesis, the mediators involved are likely to differ in time and between afflicted individuals. The paracrine mediators that affect ASM contractility directly and indirectly are given in light and dark gray respectively. The endocrine mediators affecting ASM contractility are given in bold. All, angiotensin II; ACh, acetylcholine; ANP, A-type natriuretic peptide; BDNF, brain-derived neurotrophic factor; BK, bradykinin; BNP, B-type natriuretic peptide; CNP, C-type natriuretic peptide; CT1, cardiotrophin 1; CXCL8, ligand 8 of the CXC subfamily of chemokines (also called IL8); DHEA, dehydroepiandrosterone; EETs, epoxyeicosatrienoic acids; EGF, epidermal growth factor; ET1, endothelin 1; GABA, gamma-aminobutyric acid; GM-CSF, granulocyte-macrophage colony-stimulating factor; GRP, gastrin-releasing peptide; $\mathrm{H}_{2} \mathrm{~S}$, hydrogen sulfide; HIST, histamine; 5-HT, 5-hydroxytryptamine (also called serotonin); $\mathrm{HOCl}$, hypochlorous acid; IGF1, insulin-like growth factor 1 ; IFN $\gamma$, interferon gamma; IL, interleukin; LPA, lysophosphatidic acid; NKA, neurokinin A; NO, nitric oxide; NT4, neurotrophin 4; LIF, leukemia inhibitory factor; LT, leukotriene; PACAP, pituitary adenylate cyclase-activating peptide; $P A F$, platelet-activating factor; PDGFAB, platelet-derived growth factor $A B ; P G$, prostaglandin; SP, substance $P$; S1P, sphingosine-1-phosphate; TGF $\beta 1$, transforming growth factor beta 1 ; TNF $\alpha$, tumor necrosis factor alpha; TXA 2 , thromboxane $A_{2}$; UPA, urokinase-type plasminogen activator; VIP, vasoactive intestinal peptide.

Published by Bioscientifica Ltd. 


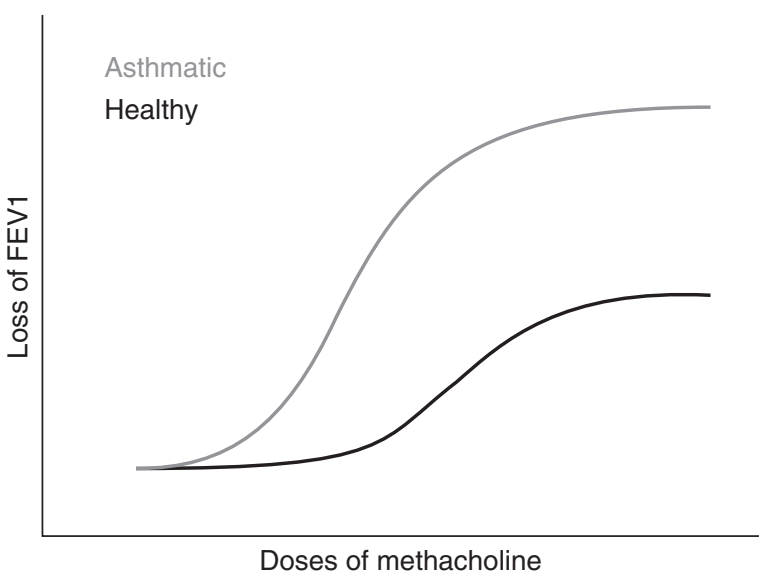

Figure 2

Airway responsiveness is increased in asthmatics. The level of airway responsiveness is assessed by measuring the decline of forced expiratory volume in $1 \mathrm{~s}$ (FEV1) before and after each incremental doses of inhaled methacholine. While healthy individuals (black curve) demonstrate normal airway responsiveness, asthmatic individuals (grey curve) demonstrate increased airway responsiveness, called hyperresponsiveness (AHR).

level of airway responsiveness (Bosse et al. 2010). The level of airway responsiveness is also variable in time, in great part due to the contractile plasticity of ASM.

\section{ASM plasticity}

The response of ASM to a given stimulus is not fixed but rather plastic (i.e. adaptable). A diverse array of mediators influences the contractile capacity of ASM. Inflammationderived spasmogens, such as leukotrienes, histamine, prostaglandin $\mathrm{D}_{2}$, and many others, stimulate ASM to contract. The expression and activity of spasmogens are often dysregulated in asthmatic lungs. In addition to triggering ASM contraction, sustained exposure to spasmogens increases ASM contractile capacity over time (Bosse et al. 2009, Pascoe et al. 2012). Many other mediators, although not spasmogenic themselves, can potentiate the contractile response of ASM to spasmogens. This is the case for many environmental factors that trigger asthma, such as viruses, allergens, and pollutants, as well as endogenous mediators that are produced in response to environmental factors, such as tumor necrosis factor alpha (TNF $\alpha$ ), interleukin 13 (IL13), and IL1 $\beta$ (reviewed in Bosse (2012)). Alternatively, other mediators attenuate the contractile effect of spasmogens. This is the case for many proteases that catabolize spasmogens, such as acetylcholinesterases (Mitchell et al. 1991), which degrade acetylcholine, neutral endopeptidases (Ratti et al. 2001), which degrade spasmogenic tachykinins such as substance P and neurokinin A, and acetylhydrolase (Stafforini et al. 1999), which degrades platelet-activating factor.

Conversely, a diverse array of mediators influence the relaxing capacity of ASM. Many endogenous bronchodilators, such as nitric oxide, prostaglandin $\mathrm{E}_{2}$, prostacyclin, and many others, stimulate ASM to relax. The expression and activity of bronchodilators are often dysregulated in asthmatic lungs. Other mediators, although not bronchodilators themselves, can potentiate the relaxing effect of bronchodilators. Among other examples cited below, this is the case for glycine (Yim et al. 2011) and dopamine (Mizuta et al. 2012). Alternatively, other mediators attenuate the relaxing effect of bronchodilators. This is the case for many inflammatory insults, such as lipopolysaccharides, allergens, and viruses, as well as many endogenous mediators, such as TNF $\alpha$, IL13, and sphingosine-1-phosphate (Bosse 2012).

Mechanical stress can also alter ASM contractility (Fredberg et al. 1997, Lavoie et al. 2012, Noble et al. 2013, Pascoe et al. 2013). For example, the change in length that ASM undergoes during breathing maneuvers, such as during a deep inspiration, decreases the contractile capacity of ASM.

The kinetics of change in ASM response to a given stimulus can thus occur at different rates. The kinetics of change fluctuates to such an extent that it can be measured using the following timescales: i) timescales of hours and days, in the case of inflammatory mediators; ii) a timescale of minutes, in the case of the gain of contractile capacity induced by a sustained exposure to spasmogens; or iii) timescales of seconds and fraction of seconds, in the case of the decline of force induced by changes in the ASM length caused by breathing maneuvers. Together, these results indicate that the magnitude of the response of ASM to a given stimulus (e.g. a chosen dose of methacholine) depends on its current state of activation, the external cues to which it has been previously exposed, and its length history. The plasticity of ASM contractility is of high significance, as it is likely to underlie the time-dependent variability of airway responsiveness.

\section{Asthma treatments}

Owing to the prominent role played by ASM contraction in the manifestation of symptoms, it is not surprising that exogenous bronchodilators are the most prescribed drugs to treat asthma (von Mutius \& Drazen 2012). Among bronchodilators, the $\beta_{2}$-agonists are the most widely used.

Published by Bioscientifica Ltd 
For the more severe forms of asthma, a proper treatment regimen also includes inhaled glucocorticoids. Glucocorticoids act partially by decreasing the level of ASM activation, mainly indirectly, but also directly, by decreasing the expression of inflammation-derived spasmogens (see below). It is fascinating that the two pillar classes of drugs to treat asthma are mimetics of endogenous mediators that are secreted by adrenal glands; $\beta_{2}$-agonists are catecholamine mimetics selective for the adrenergic $\beta_{2}$ receptor and glucocorticoids are mimetics of endogenous corticosteroids. Despite that, the level of ASM activation is mainly regarded as being under the control of a paracrine mode of regulation. Indeed, dysregulated releases of spasmogens and bronchodilators by epithelial cells, nerves, and, most importantly, inflammatory cells that are mobilized in vicinity of ASM are considered at the origin of the elevated level of ASM activation in asthma. It is also not intuitively appealing to study organs other than the lungs, such as the adrenals, to elucidate the underlying mechanisms responsible for the excessive airway narrowing in asthma. However, this may just be a misconception. Mounting evidence indicates that ASM contractility is influenced by endocrine factors. In this review article,
I suggest that the regulation of ASM contractility by mediators secreted by remote organs is overlooked.

\section{Mediators released by remote organs on ASM contraction}

The regulation of ASM contractility by remote organs can provide important clues to further our understanding of asthma pathogenesis and to elucidate the origin of asthma heterogeneity (Holgate 2011, Wenzel 2013). It may also lead to the development of alternative treatments, which would be important to fulfill an unmet need in patients who are either refractory or not adequately controlled by current asthma treatments (Barnes \& Adcock 2009, Bousquet et al. 2009). The following section highlights seminal discoveries that have demonstrated regulatory functions of mediators generally assigned to other organs on airway contractility (Fig. 3). Although this field of research adds a supplemental layer of complexity to the control of ASM contractility, the evidences suggest that it can no longer be ignored. It is also important to point out that several hormones can modify the immune response and the ensuing inflammatory response to inhaled

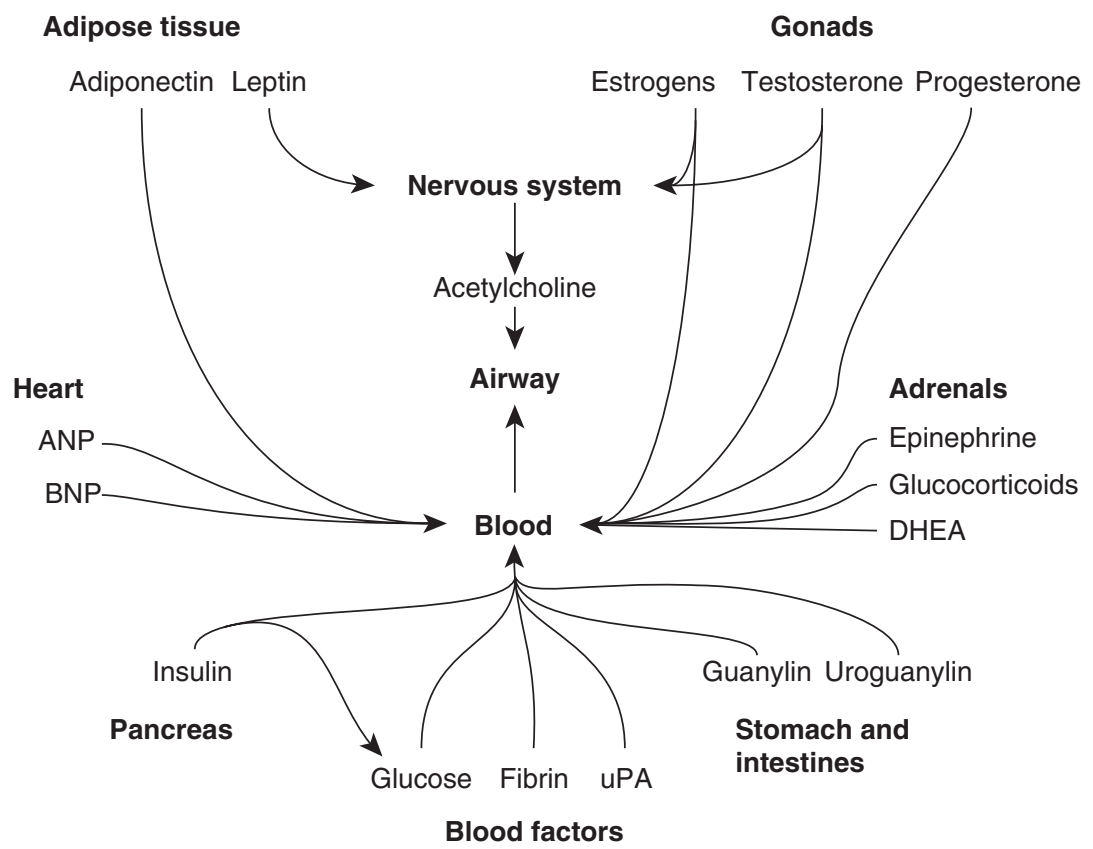

Figure 3

Mediators secreted by remote organs influence airway contractility. The mediators can affect airway contractility directly, by relaxing or contracting airway smooth muscle (ASM), or indirectly, by increasing or decreasing the responsiveness to spasmogens and bronchodilators. Their effect can also require supplementary intermediates. For example, estrogen, testosterone, and leptin act, at least partially, via the nervous system to influence the vagal parasympathetic input that controls the level of cholinergic activation of ASM. Another example is insulin, which affects blood glucose concentration that, in turn, affects the contractile capacity of ASM. More details are provided in the text. Abbreviations are provided in the legend to Fig. 1. http://joe.endocrinology-journals.org DOI: $10.1530 / J O E-14-0220$
(C) 2014 Society for Endocrinology Printed in Great Britain
Published by Bioscientifica Ltd 
environmental factors that trigger asthma. In turn, this can increase the level of airway responsiveness by altering, or not, the contractile capacity of ASM. For the purpose of clarity, the endocrine regulation of the lung immune system is not addressed in detail in the present review. Readers are referred to recent reviews that are covering this particular topic (Townsend et al. 2012a, Wright 2012, Sood \& Shore 2013).

\section{Adrenals}

Epinephrine Epinephrine has long been recognized for its potent bronchodilator effect (von Mutius \& Drazen 2012). Epinephrine acts on ASM by binding on the same receptors as the $\beta_{2}$-agonists. However, whether or not the endocrine regulation of airway contractility by endogenous epinephrine is impaired in asthma is yet to be elucidated. The fact that $\beta$-blockers induce bronchoconstriction certainly indicates that the bronchodilator effect of endogenous catecholamines, such as epinephrine, is omnipresent (Ind et al. 1985a, 1989). Severe asthmatics also fail to raise their plasma level of epinephrine during an acute episode of asthma, and this failure can play a role in the manifestation of symptoms (Ind et al. 1985b). $\beta$-blockers are also contraindicated for asthma patients, which also testifies that circulating catecholamines are still suspected to contribute to airway patency. Interestingly, certain asthma triggers, such as respiratory syncytial virus, may alter bronchoconstriction in an animal model of asthma by altering the level of endogenous catecholamines (Li et al. 2012).

Glucocorticoids Glucocorticoids are the mainstay therapy for the treatment of mild to severe forms of asthma. In addition to their well-recognized antiinflammatory virtue, glucocorticoids attenuate ASM contractility. Part of it is mediated by direct and indirect genomic (i.e. transcriptional) effects (Yick et al. 2013), and part of it is exerted by a rapid non-genomic effect (Sun et al. 2006). Indeed, acute or prolonged exposure to glucocorticoids reduces the contraction elicited by spasmogens and potentiates the relaxing response to $\beta_{2}$-adrenergic receptor activation. The mechanisms involved are several and have been reviewed previously (Hirst \& Lee 1998).

DHEA Dehydroepiandrosterone (DHEA), a metabolic intermediate in the synthesis of androgens and estrogens, is the most abundant steroid produced by the adrenals and the one found at the highest concentration in the circulation. DHEA inhibits the contraction of ASM elicited by either spasmogens or an allergen (Espinoza et al. 2013). DHEA also suppresses the in vivo allergic response (Espinoza et al. 2013) and the development of AHR (Cui et al. 2008) induced by allergic airway inflammation in animals. Most importantly in humans, nebulized DHEA is also successful to improve asthma control (Wenzel et al. 2010).

\section{Pancreas}

Insulin The mutual exclusion of type 1 diabetes, a disease in which insulin is deficient, and asthma led to the suspicion that insulin may contribute to asthma (Stene $\&$ Nafstad 2001). Association studies that report relationships between insulin and asthma abound. Insulin resistance, a complication in which insulin is overexpressed, is frequent in children with asthma (Arshi et al. 2010, Cottrell et al. 2011) and is associated with asthma-like symptoms in adults (Thuesen et al. 2009). Insulin resistance is actually a potential risk factor for asthma (Al-Shawwa et al. 2007) and is suggested to drive the widely discussed association between obesity and asthma (Husemoen et al. 2008).

The mechanisms by which insulin altered the development/severity of asthma can certainly be several. However, many reports indicate that insulin adversely influences airway contractility. In vivo, inverse association exists between blood levels of insulin and lung function (Huang et al. 2012). Supplementation of insulin also causes mild decrease in pulmonary function (Ceglia et al. 2006) and increases airway responsiveness to methacholine (Terzano et al. 2009). The absence of insulin in diabetic rats also down-regulates airway responsiveness (Cavalher-Machado et al. 2004). Ex vivo, insulin is actually capable of causing a sustained contraction of ASM (Schaafsma et al. 2007). Insulin also increases the capacity of ASM to generate force in response to spasmogens (Gosens et al. 2003). The potentiation of insulin on the contractile effect of spasmogens is mediated by the transformation of ASM into a hypercontractile phenotype (Gosens et al. 2003, Schaafsma et al. 2007, Dekkers et al. 2009) and a decreased function of the inhibitory muscarinic $\mathrm{M}_{2}$ receptors (Belmonte et al. 1997, 1998, Coulson et al. 2002). These results have recently been confirmed in rats (Nie et al. 2014).

Insulin may also affect ASM contractility by altering blood glucose concentration. Glucose concentration in airway lining fluid of non-diseased subjects was estimated to be 12.5 times lower than blood glucose concentration (Baker et al. 2007). Glucose concentration in airway secretion increases when blood glucose concentration

Published by Bioscientifica Ltd. 
reaches $6.7-9.7 \mathrm{mmol} / \mathrm{l}$ (Wood et al. 2004). This is of considerable interest, especially for diabetics, because glucose increases the contractile capacity of ASM (Cazzola et al. 2012). Together, these results offer a potential explanation for the association between blood glucose concentration and impaired lung function (Walter et al. 2003, Davis et al. 2004).

\section{Adipose tissue}

Leptin Leptin is a satiety hormone predominantly expressed in adipocytes, especially in subcutaneous adipose tissue. OBR (LEPR), the leptin receptor, is expressed on ASM (Nair et al. 2008). However, leptin has no direct effect on ASM contraction (Nair et al. 2008, Arteaga-Solis et al. 2013). Leptin rather acts through the central nervous system to attenuate the constitutive muscarinic activation of ASM that emanates from the parasympathetic inputs of the vagi (Arteaga-Solis et al. 2013). The fact that leptin-deficient $(o b / o b)$ and leptin receptor-deficient $(d b / d b)$ mice are hyperresponsive is also supportive of the bronchodilator effect of leptin (Shore et al. 2003, Lu et al. 2006, Johnston et al. 2007, Arteaga-Solis et al. 2013). Leptin and leptin receptor deficiencies also worsen AHR in a murine model of asthma elicited by ozone exposure (Shore et al. 2003, Lu et al. 2006). In addition, infusion of leptin intracerebroventricularly successfully inhibits AHR observed in high-fat diet-induced obese mice, $o b / o b$ but not $d b / d b$ mice, as well as in mice with allergic airway inflammation (Arteaga-Solis et al. 2013).

However, the effect of leptin in the context of asthma is not clear. This subject has been reviewed recently (Sood $\&$ Shore 2013). The level of leptin in the blood and adipose tissue is generally elevated in asthmatics. The blood level further increases during exacerbation (Tsaroucha et al. 2013) and following allergen challenge (Shore et al. 2005). Circulating level of leptin also correlates inversely with lung function (Tsaroucha et al. 2013) and the expression of leptin in adipose tissue positively correlates with the level of airway responsiveness (Sideleva et al. 2012). In agreement with a potentially deleterious effect of leptin in asthma, continuous infusion of leptin by subcutaneously implanted micro-osmotic pumps aggravates AHR in mice sensitized and challenged with an allergen (Shore et al. 2005). This later result may seem to be counterintuitive to the protective effect on airway tone mentioned above (Arteaga-Solis et al. 2013). However, the method of leptin delivery was different between these studies; i.e. i.c.v. (Arteaga-Solis et al. 2013) vs implanted micro-osmotic pumps (Shore et al. 2005). Together, these results indicate that the route of leptin administration can greatly affect the outcome. Systemic delivery by microosmotic pumps may decrease lung function in the context of allergic inflammation by enhancing the immunization process (Shore et al. 2005, Johnston et al. 2007), while i.c.v. administration may ameliorate lung function with or without inflammation by mitigating the contractile effect of the parasympathetic nervous system on the airways (Arteaga-Solis et al. 2013).

Adiponectin The role of adiponectin in asthma has been reviewed recently (Sood \& Shore 2013). Adiponectin is an adipokine that is mainly produced by visceral fat. It is an insulin-sensitizing hormone and generally has anti-inflammatory effects attributed. Several studies have demonstrated the relationships between adiponectin expression and asthma (Sood \& Shore 2013). Increased serum levels of adiponectin seem to confer protection against asthma (Sood et al. 2008) and low serum levels predict future risk of asthma (Sood et al. 2012). The protective association of adiponectin with asthma is clearer in women than in men (Sood \& Shore 2013). Adiponectin level is also decreased during asthma exacerbation in humans (Tsaroucha et al. 2013) and mouse models (Shore et al. 2006).

The potential mechanistic links between adiponectin and AHR were inferred from animals and in vitro studies (Sood \& Shore 2013). Both adiponectin receptors, ADIPOR1 and ADIPOR2, are expressed in human ASM cells (Shin et al. 2008). A direct effect of adiponectin on ASM contractility is suspected because AHR is attenuated in allergic mouse models of asthma treated with adiponectin (Shore et al. 2006, Ionescu et al. 2012). However, the direct effect of adiponectin on ASM contractility remains unknown.

\section{Blood-derived factors}

Fibrin Fibrin is formed from the cleavage of fibrinogen by thrombin. It has an important role in blood clotting. However, fibrin is also detected along the luminal surface of distal airways in patients dying from asthma (Wagers et al. 2004). Inverse association exists between lung function and blood levels of fibrinogen (Thyagarajan et al. 2006, Huang et al. 2012). Although the effect of fibrin on ASM is undefined, mice lacking fibrinogen demonstrate an attenuated AHR in the context of allergic airway inflammation (Riesenfeld et al. 2012). Additionally, a combination of aerosolized fibrinogen and thrombin increases airway responsiveness in mice

Published by Bioscientifica Ltd 
(Wagers et al. 2004). However, this effect seems largely independent of a direct action on ASM. It is rather related to a decrease in surface tension, owing to the ability of fibrin to inactivate the surfactant.

Urokinase-type plasminogen activator Urokinase-type plasminogen activator (uPA) is a serine protease that cleaves plasminogen into plasmin, a thrombolytic enzyme. Despite the fact that uPA may attenuate airway responsiveness by its fibrinolytic activity (Wagers et al. 2004), it may also foster ASM contractility. uPA is not capable of triggering ASM contraction directly but increases ASM sensitivity to acetylcholine (Nassar et al. 2010). Accordingly, ASM from mice deficient in uPA demonstrates reduced sensitivity to acetylcholine (Nassar et al. 2010). The effect is independent of uPA receptor and rather relies on the binding and cleavage of the $\mathrm{N}$-methylD-aspartate receptor 1 (NMDAR1 (GRIN1)).

\section{Stomach and intestines}

Guanylin and uroguanylin Guanylin and uroguanylin are small peptide hormones mainly studied for their effects on gastrointestinal and renal systems. Uroguanylin and guanylin are mainly produced by the intestinal mucosa in response to salt load. As uroguanylin is found in the blood and urine, the possibility that its release from the intestines can act on distant organs such as the airways cannot be precluded, especially in the context of inflammation where vascular permeability is increased. In fact, even in normal conditions, the effects of guanylin peptides on the functions of other organs, such as the kidneys (Moss et al. 2008) and the hypothalamus (Valentino et al. 2011), are achieved through endocrine mechanisms.

The presence of mRNA for uroguanylin receptor, the guanylyl cyclase $\mathrm{C}$ receptor, in the lung was the foundational discovery that had led to the investigation of the effects of guanylin and uroguanylin on airway functions. In the case of uroguanylin, inhalation or i.v. administration inhibits the increased respiratory system resistance induced by either allergen or leukotriene challenge (Ohbayashi \& Yamaki 2000). This in vivo effect of uroguanylin is mediated, at least partially, by its ability to relax ASM (Ohbayashi et al. 1998). In the case of guanylin, its effects on both in vivo bronchodilation and relaxation of isolated ASM are rather marginal (Ohbayashi et al. 1998). Together, these results suggest that uroguanylin, and to a lesser extent guanylin, may influence airway contractility.
Gastrin-releasing peptide Gastrin-releasing peptide (GRP) is a neuropeptide that stimulates the release of gastrin from the $G$ cells of the stomach. Blocking GRP prevents the development of AHR in murine models of asthma induced by either ozone or allergen exposure (Zhou et al. 2011). Whether these in vivo effects are mediated by a direct effect on ASM contraction is not completely clear as GRP blockage also abrogates the inflammatory response. However, GRP contracts ASM more potently than substance $\mathrm{P}$, a prototypical spasmogen (Lach et al. 1993).

\section{Thyroid}

Triiodothyronine and thyroxine The effect of thyroid hormones on airway contractility is not clear. On one hand, rats rendered hypothyroid by thyroidectomy demonstrate an attenuated susceptibility for the development of experimental asthma, and this impairment is reestablished by supplementation with thyroxine $\left(\mathrm{T}_{4}\right.$; Manzolli et al. 1999). On the other hand, triiodothyronine $\left(\mathrm{T}_{3}\right)$ supplementation in euthyroid asthmatic children was proven to be beneficial to relieve symptoms and to taper down the usage of asthma medication (abdel Khalek et al. 1991). It may sound counterintuitive that the absence of thyroid hormone is protective in rats and adding $T_{3}$ in asthmatic children with already normal levels of thyroid hormones is beneficial. Together, these observations suggest that the relationship between thyroid hormones and asthma risk is complex. Recent evidence has suggested that a polymorphism in the gene encoding the thyroid hormone receptor influences the response to bronchodilators (Duan et al. 2013). This suggests that thyroid hormones affect asthma diathesis at least in part by mechanisms altering airway contractility.

It is likely that $T_{3}$ and $T_{4}$ can be either beneficial or deleterious in asthma. The direction of the effect probably depends on: i) the type of asthma and the mediators involved in excessive airway narrowing (Fig. 1); ii) the facets on which thyroid hormones are mainly intervening in any individual to either protect or exacerbate asthma (sensitization/inflammation, ASM contraction, etc.); and iii) the genetic predispositions to respond to either the beneficial or deleterious effect of thyroid hormones.

\section{Heart}

A-type natriuretic peptide Cardiac regulation of airway contractility sounds improbable. However, A-type natriuretic peptide (ANP), which is mainly secreted by

Published by Bioscientifica Ltd 
the cardiac atria, is a potent bronchodilator in asthmatics (Hulks \& Thomson 1994, Angus et al. 1996). The degree of bronchodilation achieved by infused ANP is very similar to the one obtained with $\beta_{2}$-agonists. The bronchodilator effect is mediated by direct relaxation of ASM (Hamel \& Ford-Hutchinson 1986). The effect of ANP is quite transient, though, and more potent when administered by infusion than by inhalation (Angus et al. 1996). The bronchodilator efficacy of ANP either by inhalation (Angus et al. 1996) or by infusion (Angus et al. 1995) is prolonged by pretreatment with the neutral endopeptidase inhibitor thiorphan, suggesting that its transient action in mainly due to rapid degradation.

B-type natriuretic peptide B-type natriuretic peptide (BNP), which is predominantly secreted by the cardiac ventricles (Mukoyama et al. 1991), is another cardiac hormone that can potentially affect ASM tone. In fact, recombinant BNP is a potent bronchodilator in asthmatic patients, just as potent as $\beta_{2}$-agonists (Akerman et al. 2006). BNP mechanism of action also involved ASM relaxation (Matera et al. 2009, Edelson et al. 2013). However, the relaxing effect is mediated indirectly through the epithelium (Matera et al. 2011).

\section{Gonads}

Estrogens Several lines of evidence suggest that estrogens, such as estradiol, are bronchoprotective in asthma. Estrogen relaxes pre-contracted ASM preparations (Pang et al. 2002) and potentiates the relaxation induced by catecholamines and $\beta_{2}$-agonists (Foster et al. 1983, Townsend et al. 2012b). Estrogens also reduce the increased contraction observed in ASM passively sensitized with serum of atopic asthmatics (Dimitropoulou et al. 2005), as well as the in vivo responsiveness to an aerosolized mixture of spasmogens (Pang et al. 2002). Estrogen is also accountable for the sex disparity in the development of AHR to allergen exposure (Matsubara et al. 2008). On one hand, females are protected from allergic inflammationinduced AHR, and this is reversed by either ovariectomy or by treatment with an estrogen antagonist. On the other hand, treatment of males with estrogen protected them from AHR induced by allergic airway inflammation (Matsubara et al. 2008). Estrogen replacement therapy in ovariectomized mice also attenuates the development of airway dysfunction elicited by allergic airway inflammation (Dimitropoulou et al. 2009). Additionally, female estrogen receptor alpha-deficient mice are more sensitive to methacholine aerosol, either in the presence or the absence of allergic airway inflammation (Carey et al. 2007). This hypercontractile phenotype in receptor $\alpha$-deficient mice is associated with decreased CHRM2 expression and function (Carey et al. 2007). Finally, low dose, but not high dose, of estrogens decreases airway responsiveness in ovariectomized rats in the absence of airway inflammation (Degano et al. 2003). This occurs in conjunction with decreased responsiveness of isolated ASM to acetylcholine, associated with an increased release of acetylcholinesterase from the epithelium (Degano et al. 2001). In contradistinction, a high dose of estrogens increases ASM contractility ex vivo and decreases lung function in vivo (Degano et al. 2003). The dose-dependent dichotomy of estrogen on ASM contractility may be accountable for the proposed deleterious effect of estrogen on asthma outcomes in humans (Lieberman et al. 1995a, Troisi et al. 1995). Despite these red flag studies, estrogen therapy in humans is generally beneficial in asthma, as it decreases airway responsiveness (Villa et al. 1990, Lieberman et al. 1995b) and improves lung function (Carlson et al. 2001) and symptoms (Myers \& Sherman 1994, Chandler et al. 1997).

Androgens Androgens, such as testosterone, have an acute, non-genomic, and non-estrogenic effect on ASM activation (Kouloumenta et al. 2006, Bordallo et al. 2008, Montano et al. 2014). The direction of the effect depends on the state of ASM activation. On one hand, androgens relax pre-contracted ASM (Kouloumenta et al. 2006, Bordallo et al. 2008, Montano et al. 2014) and potentiate the relaxing effect of $\beta_{2}$-agonists (Foster et al. 1983, Bordallo et al. 2008), which suggest an overall bronchodilator effect. On the other hand, in the same ASM preparations and at the same concentrations, androgens potentiate the contractile response to a spasmogen, which suggest a constrictor effect (Bordallo et al. 2008). The controversy is also observed in vivo. On one hand, i.v. administration of androgens almost completely abrogates the increased lung resistance elicited by allergen challenge in sensitized animals (Montano et al. 2014). Testosterone therapy is also salutary in the treatment of symptoms of women suffering from premenstrual asthma (Wulfsohn et al. 1964). One the other hand, indirect evidences suggest that androgens foster contraction. For example, the spontaneously greater level of airway responsiveness observed in healthy male mice compared with females is eliminated by castration (Card et al. 2007). Administration of testosterone to either females or castrated males also increases airway responsiveness to methacholine (Card et al. 2007). The sex disparities in airway responsiveness

Published by Bioscientifica Ltd. 
and the potentiating effect of testosterone on airway responsiveness are abrogated by bilateral vagotomy, suggesting that testosterone increases airway responsiveness indirectly in vivo by acting through the vagal nerves (Card et al. 2007).

Progesterone The effect of progesterone on airway contractility has received less attention. Progesterone and one of its derivatives, $5 \beta$-pregnenolone, attenuate the contraction of isolated ASM (Perusquia et al. 1997). Progesterone also increases the relaxation induced by $\beta_{2}$ agonists (Foster et al. 1983). In vivo, progesterone does not affect the level of airway responsiveness in healthy mice (Hellings et al. 2003) but amplifies the development of AHR in a murine model of asthma (Hellings et al. 2003). The deleterious effect of progesterone on AHR seems to be a consequence of aggravated allergic airway inflammation (Hellings et al. 2003). This demonstrates that the use of a single mediator that relaxes ASM does not guarantee a beneficial outcome in a lung disorder as complex as asthma. Hormones, in particular, display pleiotropic effects and can clearly affect differently, and sometimes in opposite directions, the many facets of asthma. In vivo, some evidence suggests that progesterone can be beneficial in humans. For example, i.m. administration of progesterone is beneficial in a subgroup of asthmatics (Beynon et al. 1988).

The effect of sex hormones on asthma, airway responsiveness, and ASM contractility has received considerable interest (Townsend et al. 2012a). The results obtained so far are informative and promising, but not yet permissive to conclusive statements due to reported discrepancies. Segregating the patients according to sex and stage of life may help but may not be sufficient to predict the outcomes of hormonal therapy. The underlying mechanisms responsible for the manifestation of asthma symptoms are more likely to dictate whether hormonal therapy would be salutary, useless, or detrimental. Thus, the potential to improve the quality of life of asthmatics by tailored hormonal therapy exists, but there is probably no unique treatment regimen that will be efficacious for all afflicted patients.

\section{Concluding remarks and future perspectives}

The symptoms of asthma are largely related to airway narrowing caused by ASM shortening. Even though ASM is the effector tissue causing excessive airway narrowing, the defects that lead to its malfunction can originate from anywhere in the body. However, it is customary in asthma research to focus on lung factors that affect, via a paracrine mode of regulation, the contraction of ASM. The mechanisms by which dysfunctions of distant organs can affect airway contractility and asthma development/ severity are also not intuitively appealing and have commensurately received less attention.

Nevertheless, solid evidences now indicate that ASM contractility is under the influence of many blood-derived mediators that originate from diverse organs, including the adrenals, pancreas, adipose tissue, gonads, heart, intestines, and stomach (Fig. 2). These mediators can act directly on the airways by either modifying the level of ASM activation (Fig. 1) or by altering the response to spasmogens and bronchodilators. Additionally, they can act indirectly via the brain or local nerve endings to amplify the parasympathetic influence of the vagi on the cholinergic activation of ASM. Together, these results highlight the importance of studying the whole organism, in addition to isolated cells, tissues, and organs.

The slow progress in asthma therapy (Holgate 2011, von Mutius \& Drazen 2012), despite the extensive and long-standing research interest for that lung disorder, suggests that important mediators might have been overlooked. The endocrine regulation of airway contractility and its dysregulation in asthma are key areas of research that clearly deserve further investigation. These avenues of research are not conventionally addressed by current scientific approaches and are conducive to unexpected and breaking discoveries. A better understanding of the endocrine regulation of ASM contractility can actually be a prerequisite to leap forward the implementation of personalized medicine.

\section{Declaration of interest}

The author declares that there is no conflict of interest that could be perceived as prejudicing the impartiality of the review.

\section{Funding}

This review did not receive any specific grant from any funding agency in the public, commercial or not-for-profit sector.

\section{References}

Akerman MJ, Yaegashi M, Khiangte Z, Murugan AT, Abe O \& Marmur JD 2006 Bronchodilator effect of infused B-type natriuretic peptide in asthma. Chest 130 66-72. (doi:10.1378/chest.130.1.66)

Al-Shawwa BA, Al-Huniti NH, DeMattia L \& Gershan W 2007 Asthma and insulin resistance in morbidly obese children and adolescents. Journal of Asthma 44 469-473. (doi:10.1080/02770900701423597) http://joe.endocrinology-journals.org DOI: $10.1530 / J O E-14-0220$
C) 2014 Society for Endocrinology Printed in Great Britain
Published by Bioscientifica Ltd 
Angus RM, Millar EA, Chalmers GW \& Thomson NC 1995 Effect of inhaled atrial natriuretic peptide and a neutral endopeptidase inhibitor on histamine-induced bronchoconstriction. American Journal of Respiratory and Critical Care Medicine 151 2003-2005. (doi:10.1164/ajrccm.151.6. 7767551)

Angus RM, Millar EA, Chalmers GW \& Thomson NC 1996 Effect of inhaled thiorphan, a neutral endopeptidase inhibitor, on the bronchodilator response to inhaled atrial natriuretic peptide (ANP). Thorax 51 71-74. (doi:10.1136/thx.51.1.71)

Arshi M, Cardinal J, Hill RJ, Davies PS \& Wainwright C 2010 Asthma and insulin resistance in children. Respirology 15 779-784. (doi:10.1111/ j.1440-1843.2010.01767.x)

Arteaga-Solis E, Zee T, Emala CW, Vinson C, Wess J \& Karsenty G 2013 Inhibition of leptin regulation of parasympathetic signaling as a cause of extreme body weight-associated asthma. Cell Metabolism 17 35-48. (doi:10.1016/j.cmet.2012.12.004)

Baker EH, Clark N, Brennan AL, Fisher DA, Gyi KM, Hodson ME, Philips BJ, Baines DL \& Wood DM 2007 Hyperglycemia and cystic fibrosis alter respiratory fluid glucose concentrations estimated by breath condensate analysis. Journal of Applied Physiology 102 1969-1975. (doi:10.1152/japplphysiol.01425.2006)

Barnes PJ \& Adcock IM 2009 Glucocorticoid resistance in inflammatory diseases. Lancet 373 1905-1917. (doi:10.1016/S0140-6736(09)60326-3)

Bateman ED, Hurd SS, Barnes PJ, Bousquet J, Drazen JM, FitzGerald M, Gibson P, Ohta K, O’Byrne P, Pedersen SE et al. 2008 Global strategy for asthma management and prevention: GINA executive summary. European Respiratory Journal 31 143-178. (doi:10.1183/09031936. 00138707)

Belmonte KE, Jacoby DB \& Fryer AD 1997 Increased function of inhibitory neuronal M2 muscarinic receptors in diabetic rat lungs. British Journal of Pharmacology 121 1287-1294. (doi:10.1038/sj.bjp.0701274)

Belmonte KE, Fryer AD \& Costello RW 1998 Role of insulin in antigeninduced airway eosinophilia and neuronal M2 muscarinic receptor dysfunction. Journal of Applied Physiology 85 1708-1718.

Beynon HL, Garbett ND \& Barnes PJ 1988 Severe premenstrual exacerbations of asthma: effect of intramuscular progesterone. Lancet 2 370-372. (doi:10.1016/S0140-6736(88)92837-1)

Bordallo J, de Boto MJ, Meana C, Velasco L, Bordallo C, Suarez L, Cantabrana B \& Sanchez M 2008 Modulatory role of endogenous androgens on airway smooth muscle tone in isolated guinea-pig and bovine trachea; involvement of $\beta 2$-adrenoceptors, the polyamine system and external calcium. European Journal of Pharmacology $\mathbf{6 0 1}$ 154-162. (doi:10.1016/j.ejphar.2008.10.039)

Bosse Y 2012 Asthmatic airway hyperresponsiveness: the ants in the tree. Trends in Molecular Medicine 18 627-633. (doi:10.1016/j.molmed.2012. 09.002)

Bosse Y, Chin LY, Pare PD \& Seow CY 2009 Adaptation of airway smooth muscle to basal tone: relevance to airway hyperresponsiveness. American Journal of Respiratory Cell and Molecular Biology 40 13-18. (doi:10.1165/rcmb.2008-01500C)

Bosse Y, Riesenfeld EP, Pare PD \& Irvin CG 2010 It's not all smooth muscle: nonsmooth muscle elements in control of resistance to airflow. Annual Review of Physiology 72 437-462. (doi:10.1146/annurev-physiol021909-135851)

Bousquet J, Bachert C, Canonica GW, Casale TB, Cruz AA, Lockey RJ, Zuberbier T, Extended Global A, Asthma European Network WAO, Allergic R et al. 2009 Unmet needs in severe chronic upper airway disease (SCUAD). Journal of Allergy and Clinical Immunology $\mathbf{1 2 4}$ 428-433. (doi:10.1016/j.jaci.2009.06.027)

Card JW, Voltz JW, Ferguson CD, Carey MA, DeGraff LM, Peddada SD, Morgan DL \& Zeldin DC 2007 Male sex hormones promote vagally mediated reflex airway responsiveness to cholinergic stimulation. American Journal of Physiology. Lung Cellular and Molecular Physiology 292 L908-L914. (doi:10.1152/ajplung.00407.2006)

Carey MA, Card JW, Bradbury JA, Moorman MP, Haykal-Coates N, Gavett SH, Graves JP, Walker VR, Flake GP, Voltz JW et al. 2007
Spontaneous airway hyperresponsiveness in estrogen receptor$\alpha$-deficient mice. American Journal of Respiratory and Critical Care Medicine 175 126-135. (doi:10.1164/rccm.200509-1493OC)

Carlson CL, Cushman M, Enright PL, Cauley JA, Newman AB \& Cardiovascular Health Study Research G 2001 Hormone replacement therapy is associated with higher FEV1 in elderly women. American Journal of Respiratory and Critical Care Medicine 163 423-428. (doi:10.1164/ajrccm.163.2.2003040)

Cavalher-Machado SC, de Lima WT, Damazo AS, de Frias Carvalho V, Martins MA, e Silva PM \& Sannomiya P 2004 Down-regulation of mast cell activation and airway reactivity in diabetic rats: role of insulin. European Respiratory Journal 24 552-558. (doi:10.1183/09031936.04. 00130803)

Cazzola M, Calzetta L, Rogliani P, Lauro D, Novelli L, Page CP, Kanabar V \& Matera MG 2012 High glucose enhances responsiveness of human airways smooth muscle via the Rho/ROCK pathway. American Journal of Respiratory Cell and Molecular Biology 47 509-516. (doi:10.1165/rcmb. 2011-0449OC)

Ceglia L, Lau J \& Pittas AG 2006 Meta-analysis: efficacy and safety of inhaled insulin therapy in adults with diabetes mellitus. Annals of Internal Medicine 145 665-675. (doi:10.7326/0003-4819-145-9200611070-00009)

Chandler MH, Schuldheisz S, Phillips BA \& Muse KN 1997 Premenstrual asthma: the effect of estrogen on symptoms, pulmonary function, and ß2-receptors. Pharmacotherapy 17 224-234. (doi:10.1002/j.1875-9114. 1997.tb03703.x)

Cottrell L, Neal WA, Ice C, Perez MK \& Piedimonte G 2011 Metabolic abnormalities in children with asthma. American Journal of Respiratory and Critical Care Medicine 183 441-448. (doi:10.1164/rccm.2010040603OC)

Coulson FR, Jacoby DB \& Fryer AD 2002 Increased function of inhibitory neuronal M2 muscarinic receptors in trachea and ileum of diabetic rats. British Journal of Pharmacology 135 1355-1362. (doi:10.1038/sj.bjp. 0704602)

Crapo RO, Casaburi R, Coates AL, Enright PL, Hankinson JL, Irvin CG, MacIntyre NR, McKay RT, Wanger JS, Anderson SD et al. 2000 Guidelines for methacholine and exercise challenge testing-1999. This official statement of the American Thoracic Society was adopted by the ATS Board of Directors, July 1999. American Journal of Respiratory and Critical Care Medicine 161 309-329. (doi:10.1164/ajrccm.161.1. ats11-99)

Cui Y, Choi IS, Koh YA, Lin XH, Cho YB \& Won YH 2008 Effects of combined BCG and DHEA treatment in preventing the development of asthma. Immunological Investigations 37 191-202. (doi:10.1080/ 08820130801967833)

Davis WA, Knuiman M, Kendall P, Grange V, Davis TM \& Fremantle Diabetes Study 2004 Glycemic exposure is associated with reduced pulmonary function in type 2 diabetes: the Fremantle Diabetes Study. Diabetes Care 27 752-757. (doi:10.2337/diacare.27.3.752)

Degano B, Prevost MC, Berger P, Molimard M, Pontier S, Rami J \& Escamilla R 2001 Estradiol decreases the acetylcholine-elicited airway reactivity in ovariectomized rats through an increase in epithelial acetylcholinesterase activity. American Journal of Respiratory and Critical Care Medicine 164 1849-1854. (doi:10.1164/ajrccm.164.10.2102009)

Degano B, Mourlanette P, Valmary S, Pontier S, Prevost MC \& Escamilla R 2003 Differential effects of low and high-dose estradiol on airway reactivity in ovariectomized rats. Respiratory Physiology \& Neurobiology 138 265-274. (doi:10.1016/j.resp.2003.08.007)

Dekkers BG, Schaafsma D, Tran T, Zaagsma J \& Meurs H 2009 Insulininduced laminin expression promotes a hypercontractile airway smooth muscle phenotype. American Journal of Respiratory Cell and Molecular Biology 41 494-504. (doi:10.1165/rcmb.2008-0251OC)

Dimitropoulou C, White RE, Ownby DR \& Catravas JD 2005 Estrogen reduces carbachol-induced constriction of asthmatic airways by stimulating large-conductance voltage and calcium-dependent http://joe.endocrinology-journals.org DOI: $10.1530 / J O E-14-0220$
Cㄱ 2014 Society for Endocrinology Printed in Great Britain 
potassium channels. American Journal of Respiratory Cell and Molecular Biology 32 239-247. (doi:10.1165/rcmb.2004-0331OC)

Dimitropoulou C, Drakopanagiotakis F, Chatterjee A, Snead C \& Catravas JD 2009 Estrogen replacement therapy prevents airway dysfunction in a murine model of allergen-induced asthma. Lung $\mathbf{1 8 7}$ 116-127. (doi:10.1007/s00408-008-9129-z)

Duan QL, Du R, Lasky-Su J, Klanderman BJ, Partch AB, Peters SP, Irvin CG, Hanrahan JP, Lima JJ, Blake KV et al. 2013 A polymorphism in the thyroid hormone receptor gene is associated with bronchodilator response in asthmatics. Pharmacogenomics Journal 13 130-136. (doi:10.1038/tpj.2011.56)

Edelson JD, Makhlina M, Silvester KR, Vengurlekar SS, Chen X, Zhang J, Koziol-White CJ, Cooper PR, Hallam TJ, Hay DW et al. 2013 In vitro and in vivo pharmacological profile of PL-3994, a novel cyclic peptide (Heptcyclo(Cys-His-Phe-D-Ala-Gly-Arg-D-Nle-Asp-Arg-Ile-Ser-Cys)-Tyr-[Arg mimetic]-NH(2)) natriuretic peptide receptor-A agonist that is resistant to neutral endopeptidase and acts as a bronchodilator. Pulmonary Pharmacology \& Therapeutics 26 229-238. (doi:10.1016/j.pupt.2012. 11.001)

Espinoza J, Montano LM \& Perusquia M 2013 Nongenomic bronchodilating action elicited by dehydroepiandrosterone (DHEA) in a guinea pig asthma model. Journal of Steroid Biochemistry and Molecular Biology 138C 174-182. (doi:10.1016/j.jsbmb.2013.05.009)

Foster PS, Goldie RG \& Paterson JW 1983 Effect of steroids on $\beta$-adrenoceptor-mediated relaxation of pig bronchus. British Journal of Pharmacology 78 441-445. (doi:10.1111/j.1476-5381.1983.tb09409.x)

Fredberg JJ, Inouye D, Miller B, Nathan M, Jafari S, Raboudi SH, Butler JP \& Shore SA 1997 Airway smooth muscle, tidal stretches, and dynamically determined contractile states. American Journal of Respiratory and Critical Care Medicine 156 1752-1759. (doi:10.1164/ajrccm.156.6.9611016)

Gosens R, Nelemans SA, Hiemstra M, Grootte Bromhaar MM, Meurs H \& Zaagsma J 2003 Insulin induces a hypercontractile airway smooth muscle phenotype. European Journal of Pharmacology 481 125-131. (doi:10.1016/j.ejphar.2003.08.081)

Hamel R \& Ford-Hutchinson AW 1986 Relaxant profile of synthetic atrial natriuretic factor on guinea-pig pulmonary tissues. European Journal of Pharmacology 121 151-155. (doi:10.1016/0014-2999(86)90406-1)

Haselkorn T, Chen H, Miller DP, Fish JE, Peters SP, Weiss ST \& Jones CA 2010 Asthma control and activity limitations: insights from the Realworld Evaluation of Asthma Control and Treatment (REACT) study. Annals of Allergy, Asthma \& Immunology 104 471-477. (doi:10.1016/ j.anai.2010.04.006)

Hellings PW, Vandekerckhove P, Claeys R, Billen J, Kasran A \& Ceuppens JL 2003 Progesterone increases airway eosinophilia and hyper-responsiveness in a murine model of allergic asthma. Clinical and Experimental Allergy 33 1457-1463. (doi:10.1046/j.1365-2222.2003.01743.x)

Hirst SJ \& Lee TH 1998 Airway smooth muscle as a target of glucocorticoid action in the treatment of asthma. American Journal of Respiratory and Critical Care Medicine 158 S201-S206. (doi:10.1164/ajrccm.158.supplement_2.13tac190)

Holgate ST 2011 Asthma: a simple concept but in reality a complex disease. European Journal of Clinical Investigation 41 1339-1352. (doi:10.1111/ j.1365-2362.2011.02534.x)

Huang F, del-Rio-Navarro BE, Alcantara ST, Ontiveros JA, Cienfuegos DR, Bello Gonzalez SA, Villafana S, Bravo G \& Hong E 2012 Plasminogen activator inhibitor-1, fibrinogen, and lung function in adolescents with asthma and obesity. Endocrine Research 37 135-144. (doi:10.3109/ 07435800.2012.654555)

Hulks G \& Thomson NC 1994 High dose inhaled atrial natriuretic peptide is a bronchodilator in asthmatic subjects. European Respiratory Journal 7 1593-1597. (doi:10.1183/09031936.94.07091593)

Husemoen LL, Glumer C, Lau C, Pisinger C, Morch LS \& Linneberg A 2008 Association of obesity and insulin resistance with asthma and aeroallergen sensitization. Allergy 63 575-582. (doi:10.1111/ j.1398-9995.2007.01613.x)
Ind PW, Barnes PJ, Brown MJ \& Dollery CT 1985a Plasma histamine concentration during propranolol induced bronchoconstriction. Thorax 40 903-909. (doi:10.1136/thx.40.12.903)

Ind PW, Causon RC, Brown MJ \& Barnes PJ 1985b Circulating catecholamines in acute asthma. BMJ 290 267-269. (doi:10.1136/bmj. 290.6464.267)

Ind PW, Dixon CM, Fuller RW \& Barnes PJ 1989 Anticholinergic blockade of $\beta$-blocker-induced bronchoconstriction. American Review of Respiratory Disease 139 1390-1394. (doi:10.1164/ajrccm/139.6.1390)

Ionescu LI, Alphonse RS, Arizmendi N, Morgan B, Abel M, Eaton F, Duszyk M, Vliagoftis H, Aprahamian TR, Walsh K et al. 2012 Airway delivery of soluble factors from plastic-adherent bone marrow cells prevents murine asthma. American Journal of Respiratory Cell and Molecular Biology 46 207-216. (doi:10.1165/rcmb.2010-0391OC)

Johnston RA, Zhu M, Rivera-Sanchez YM, Lu FL, Theman TA, Flynt L \& Shore SA 2007 Allergic airway responses in obese mice. American Journal of Respiratory and Critical Care Medicine 176 650-658. (doi:10.1164/rccm.200702-323OC)

abdel Khalek K, el Kholy M, Rafik M, Fathalla M \& Heikal E 1991 Effect of triiodothyronine on cyclic AMP and pulmonary function tests in bronchial asthma. Journal of Asthma 28 425-431. (doi:10.3109/ 02770909109110625)

Kouloumenta V, Hatziefthimiou A, Paraskeva E, Gourgoulianis K \& Molyvdas PA 2006 Non-genomic effect of testosterone on airway smooth muscle. British Journal of Pharmacology 149 1083-1091. (doi:10.1038/sj.bjp.0706936)

Lach E, Haddad EB \& Gies JP 1993 Contractile effect of bombesin on guinea pig lung in vitro: involvement of gastrin-releasing peptide-preferring receptors. American Journal of Physiology 264 L80-L86.

Lavoie TL, Krishnan R, Siegel HR, Maston ED, Fredberg JJ, Solway J \& Dowell ML 2012 Dilatation of the constricted human airway by tidal expansion of lung parenchyma. American Journal of Respiratory and Critical Care Medicine 186 225-232. (doi:10.1164/rccm.201202-0368OC)

Li QG, Wu XR, Li XZ, Yu J, Xia Y, Wang AP \& Wang J 2012 Neuralendocrine mechanisms of respiratory syncytial virus-associated asthma in a rat model. Genetics and Molecular Research 11 2780-2789. (doi:10.4238/2012.August.24.3)

Lieberman D, Kopernik G, Porath A, Lazer S \& Heimer D 1995 a Sub-clinical worsening of bronchial asthma during estrogen replacement therapy in asthmatic post-menopausal women. Maturitas 21 153-157. (doi:10.1016/0378-5122(94)00890-J)

Lieberman D, Kopernic G, Porath A, Levitas E, Lazer S \& Heimer D $1995 b$ Influence of estrogen replacement therapy on airway reactivity. Respiration 62 205-208. (doi:10.1159/000196448)

Lu FL, Johnston RA, Flynt L, Theman TA, Terry RD, Schwartzman IN, Lee A $\&$ Shore SA 2006 Increased pulmonary responses to acute ozone exposure in obese $d b / d b$ mice. American Journal of Physiology. Lung Cellular and Molecular Physiology 290 L856-L865. (doi:10.1152/ajplung. 00386.2005)

Manzolli S, Macedo-Soares MF, Vianna EO \& Sannomiya P 1999 Allergic airway inflammation in hypothyroid rats. Journal of Allergy and Clinical Immunology 104 595-600. (doi:10.1016/S0091-6749(99)70329-5)

Masoli M, Fabian D, Holt S \& Beasley R 2004 The global burden of asthma: executive summary of the GINA Dissemination Committee report. Allergy 59 469-478. (doi:10.1111/j.1398-9995.2004.00526.x)

Matera MG, Calzetta L, Parascandolo V, Curradi G, Rogliani P \& Cazzola M 2009 Relaxant effect of brain natriuretic peptide in nonsensitized and passively sensitized isolated human bronchi. Pulmonary Pharmacology \& Therapeutics 22 478-482. (doi:10.1016/j.pupt.2009.04.005)

Matera MG, Calzetta L, Passeri D, Facciolo F, Rendina EA, Page C, Cazzola M \& Orlandi A 2011 Epithelium integrity is crucial for the relaxant activity of brain natriuretic peptide in human isolated bronchi. British Journal of Pharmacology 163 1740-1754. (doi:10.1111/ j.1476-5381.2011.01339.x)

Matsubara S, Swasey CH, Loader JE, Dakhama A, Joetham A, Ohnishi H, Balhorn A, Miyahara N, Takeda K \& Gelfand EW 2008 Estrogen 
determines sex differences in airway responsiveness after allergen exposure. American Journal of Respiratory Cell and Molecular Biology 38 501-508. (doi:10.1165/rcmb.2007-02980C)

Mitchell RW, Kelly E \& Leff AR 1991 Reduced activity of acetylcholinesterase in canine tracheal smooth muscle homogenates after active immune-sensitization. American Journal of Respiratory Cell and Molecular Biology 5 56-62. (doi:10.1165/ajrcmb/5.1.56)

Mizuta K, Zhang Y, Xu D, Masaki E, Panettieri RA Jr \& Emala CW 2012 The dopamine $\mathrm{D}(2)$ receptor is expressed and sensitizes adenylyl cyclase activity in airway smooth muscle. American Journal of Physiology. Lung Cellular and Molecular Physiology 302 L316-L324. (doi:10.1152/ajplung. 00130.2011)

Montano LM, Espinoza J, Flores-Soto E, Chavez J \& Perusquia M 2014 Androgens are bronchoactive drugs by relaxing airway smooth muscle and preventing bronchospasm. Journal of Endocrinology 222 1-13. (doi:10.1530/JOE-14-0074)

Moss NG, Fellner RC, Qian X, Yu SJ, Li Z, Nakazato M \& Goy MF 2008 Uroguanylin, an intestinal natriuretic peptide, is delivered to the kidney as an unprocessed propeptide. Endocrinology 149 4486-4498. (doi:10.1210/en.2007-1725)

Mukoyama M, Nakao K, Hosoda K, Suga S, Saito Y, Ogawa Y, Shirakami G, Jougasaki M, Obata K, Yasue H et al. 1991 Brain natriuretic peptide as a novel cardiac hormone in humans. Evidence for an exquisite dual natriuretic peptide system, atrial natriuretic peptide and brain natriuretic peptide. Journal of Clinical Investigation 87 1402-1412. (doi:10.1172/JCI115146)

Myers JR \& Sherman CB 1994 Should supplemental estrogens be used as steroid-sparing agents in asthmatic women? Chest 106 318-319. (doi:10.1378/chest.106.1.318)

Nair P, Radford K, Fanat A, Janssen LJ, Peters-Golden M \& Cox PG 2008 The effects of leptin on airway smooth muscle responses. American Journal of Respiratory Cell and Molecular Biology 39 475-481. (doi:10.1165/rcmb. 2007-0091OC)

Nassar T, Yarovoi S, Fanne RA, Akkawi S, Jammal M, Allen TC, Idell S, Cines DB \& Higazi AA 2010 Regulation of airway contractility by plasminogen activators through $N$-methyl-D-aspartate receptor-1. American Journal of Respiratory Cell and Molecular Biology 43 703-711. (doi:10.1165/rcmb.2009-0257OC)

National Heart Lung and Blood Institute National Asthma Education and Prevention Program 2007 Expert Panel Report 3 (EPR-3): Guidelines for the Diagnosis and Management of Asthma-Summary Report 2007. Journal of Allergy and Clinical Immunology 120 S94-S138. (doi:10.1016/ j.jaci.2007.09.029)

Nie Z, Jacoby DB \& Fryer AD 2014 Hyperinsulinemia potentiates airway responsiveness to parasympathetic nerve stimulation in obese rats. American Journal of Respiratory Cell and Molecular Biology [in press]. (doi:10.1165/rcmb.2013-0452OC)

Noble PB, Jones RL, Cairncross A, Elliot JG, Mitchell HW, James AL \& McFawn PK 2013 Airway narrowing and bronchodilation to deep inspiration in bronchial segments from subjects with and without reported asthma. Journal of Applied Physiology 114 1460-1471. (doi:10.1152/japplphysiol.01489.2012)

Ohbayashi H \& Yamaki KI 2000 Both inhalant and intravenous uroguanylin inhibit leukotriene C4-induced airway changes. Peptides 21 1467-1472. (doi:10.1016/S0196-9781(00)00299-0)

Ohbayashi H, Yamaki K, Suzuki R \& Takagi K 1998 Effects of uroguanylin and guanylin against antigen-induced bronchoconstriction and airway microvascular leakage in sensitized guinea-pigs. Life Sciences $\mathbf{6 2}$ 1833-1844. (doi:10.1016/S0024-3205(98)00149-0)

Pang JJ, Xu XB, Li HF, Zhang XY, Zheng TZ \& Qu SY 2002 Inhibition of $\beta$-estradiol on trachea smooth muscle contraction in vitro and in vivo. Acta Pharmacologica Sinica 23 273-277.

Pascoe C, Jiao Y, Seow CY, Pare PD \& Bosse Y 2012 Force oscillations simulating breathing maneuvers do not prevent force adaptation. American Journal of Respiratory Cell and Molecular Biology 47 44-49. (doi:10.1165/rcmb.2011-0429OC)
Pascoe CD, Seow CY, Pare PD \& Bosse Y 2013 Decrease of airway smooth muscle contractility induced by simulated breathing maneuvers is not simply proportional to strain. Journal of Applied Physiology 114 335-343. (doi:10.1152/japplphysiol.00870.2012)

Perusquia M, Hernandez R, Montano LM, Villalon CM \& Campos MG 1997 Inhibitory effect of sex steroids on guinea-pig airway smooth muscle contractions. Comparative Biochemistry and Physiology. Part C, Pharmacology, Toxicology \& Endocrinology 118 5-10. (doi:10.1016/S07428413(97)00029-7)

Ratti H, Zhang M \& Kunkel G 2001 Correlation between neutral endopetidase (NEP) 3.4.24.11 in serum and the degree of the bronchial hyperreactivity. Regulatory Peptides 97 181-186. (doi:10.1016/S01670115(00)00215-9)

Riesenfeld E, Allen GB, Bates JH, Poynter ME, Wu M, Aimiand S \& Lundblad LK 2012 The temporal evolution of airways hyperresponsiveness and inflammation. Journal of Allergy \& Therapy 1 1-7. (doi:10.4172/21556121.S1-005)

Schaafsma D, Gosens R, Ris JM, Zaagsma J, Meurs H \& Nelemans SA 2007 Insulin induces airway smooth muscle contraction. British Journal of Pharmacology 150 136-142. (doi:10.1038/sj.bjp.0706985)

Shin JH, Kim JH, Lee WY \& Shim JY 2008 The expression of adiponectin receptors and the effects of adiponectin and leptin on airway smooth muscle cells. Yonsei Medical Journal 49 804-810. (doi:10.3349/ymj. 2008.49.5.804)

Shore SA, Rivera-Sanchez YM, Schwartzman IN \& Johnston RA 2003 Responses to ozone are increased in obese mice. Journal of Applied Physiology 95 938-945. (doi:10.1152/japplphysiol.00336.2003)

Shore SA, Schwartzman IN, Mellema MS, Flynt L, Imrich A \& Johnston RA 2005 Effect of leptin on allergic airway responses in mice. Journal of Allergy and Clinical Immunology 115 103-109. (doi:10.1016/j.jaci.2004. 10.007)

Shore SA, Terry RD, Flynt L, Xu A \& Hug C 2006 Adiponectin attenuates allergen-induced airway inflammation and hyperresponsiveness in mice. Journal of Allergy and Clinical Immunology 118 389-395. (doi:10.1016/j.jaci.2006.04.021)

Sideleva O, Suratt BT, Black KE, Tharp WG, Pratley RE, Forgione P, Dienz O, Irvin CG \& Dixon AE 2012 Obesity and asthma: an inflammatory disease of adipose tissue not the airway. American Journal of Respiratory and Critical Care Medicine 186 598-605. (doi:10.1164/rccm.2012030573OC)

Sood A \& Shore SA 2013 Adiponectin, leptin, and resistin in asthma: basic mechanisms through population studies. Journal of Allergy $\mathbf{2 0 1 3}$ 785835. (doi:10.1155/2013/785835)

Sood A, Cui X, Qualls C, Beckett WS, Gross MD, Steffes MW, Smith LJ \& Jacobs DR Jr 2008 Association between asthma and serum adiponectin concentration in women. Thorax 63 877-882. (doi:10.1136/thx.2007. 090803)

Sood A, Qualls C, Schuyler M, Thyagarajan B, Steffes MW, Smith LJ \& Jacobs DR Jr 2012 Low serum adiponectin predicts future risk for asthma in women. American Journal of Respiratory and Critical Care Medicine $\mathbf{1 8 6}$ 41-47. (doi:10.1164/rccm.201110-1767OC)

Stafforini DM, Numao T, Tsodikov A, Vaitkus D, Fukuda T, Watanabe N, Fueki N, McIntyre TM, Zimmerman GA, Makino S et al. 1999 Deficiency of platelet-activating factor acetylhydrolase is a severity factor for asthma. Journal of Clinical Investigation 103 989-997. (doi:10.1172/ JCI5574)

Stene LC \& Nafstad P 2001 Relation between occurrence of type 1 diabetes and asthma. Lancet 357 607-608. (doi:10.1016/S0140-6736(00) 04067-8)

Sun HW, Miao CY, Liu L, Zhou J, Su DF, Wang YX \& Jiang CL 2006 Rapid inhibitory effect of glucocorticoids on airway smooth muscle contractions in guinea pigs. Steroids 71 154-159. (doi:10.1016/ j.steroids.2005.09.019)

Terzano C, Morano S, Ceccarelli D, Conti V, Paone G, Petroianni A, Graziani E, Carnovale A, Fallarino M, Gatti A et al. 2009 Effect of insulin on airway responsiveness in patients with type 2 diabetes mellitus:

Published by Bioscientifica Ltd. 
a cohort study. Journal of Asthma 46 703-707. (doi:10.1080/ 02770900903056203)

Thuesen BH, Husemoen LL, Hersoug LG, Pisinger C \& Linneberg A 2009 Insulin resistance as a predictor of incident asthma-like symptoms in adults. Clinical and Experimental Allergy 39 700-707. (doi:10.1111/ j.1365-2222.2008.03197.x)

Thyagarajan B, Jacobs DR, Apostol GG, Smith LJ, Lewis CE \& Williams OD 2006 Plasma fibrinogen and lung function: the CARDIA Study. International Journal of Epidemiology 35 1001-1008. (doi:10.1093/ije/ dyl049)

Townsend EA, Miller VM \& Prakash YS 2012a Sex differences and sex steroids in lung health and disease. Endocrine Reviews 33 1-47. (doi:10.1210/er.2010-0031)

Townsend EA, Sathish V, Thompson MA, Pabelick CM \& Prakash YS $2012 b$ Estrogen effects on human airway smooth muscle involve cAMP and protein kinase A. American Journal of Physiology. Lung Cellular and Molecular Physiology 303 L923-L928. (doi:10.1152/ajplung.00023.2012)

Troisi RJ, Speizer FE, Willett WC, Trichopoulos D \& Rosner B 1995 Menopause, postmenopausal estrogen preparations, and the risk of adult-onset asthma. A prospective cohort study. American Journal of Respiratory and Critical Care Medicine 152 1183-1188. (doi:10.1164/ ajrccm.152.4.7551368)

Tsaroucha A, Daniil Z, Malli F, Georgoulias P, Minas M, Kostikas K, Bargiota A, Zintzaras E \& Gourgoulianis KI 2013 Leptin, adiponectin, and ghrelin levels in female patients with asthma during stable and exacerbation periods. Journal of Asthma $\mathbf{5 0}$ 188-197. (doi:10.3109/ 02770903.2012.747101)

Valentino MA, Lin JE, Snook AE, Li P, Kim GW, Marszalowicz G, Magee MS, Hyslop T, Schulz S \& Waldman SA 2011 A uroguanylin-GUCY2C endocrine axis regulates feeding in mice. Journal of Clinical Investigation 121 3578-3588. (doi:10.1172/JCI57925)

Villa MP, Bernardi F, Burnaccini M, Tura A, Martelli M, Mazzanti L, Bergamaschi R \& Cacciari E 1990 Bronchial reactivity and sex hormone: study in a Turner's population. Pediatric Pulmonology 9 199-205. (doi:10.1002/ppul.1950090403)

von Mutius E \& Drazen JM 2012 A patient with asthma seeks medical advice in 1828, 1928, and 2012. New England Journal of Medicine 366 827-834. (doi:10.1056/NEJMra1102783)
Wagers SS, Norton RJ, Rinaldi LM, Bates JH, Sobel BE \& Irvin CG 2004 Extravascular fibrin, plasminogen activator, plasminogen activator inhibitors, and airway hyperresponsiveness. Journal of Clinical Investigation 114 104-111. (doi:10.1172/JCI200419569)

Walter RE, Beiser A, Givelber RJ, O'Connor GT \& Gottlieb DJ 2003 Association between glycemic state and lung function: the Framingham Heart Study. American Journal of Respiratory and Critical Care Medicine 167 911-916. (doi:10.1164/rccm.2203022)

Wenzel SE 2013 Complex phenotypes in asthma: current definitions. Pulmonary Pharmacology \& Therapeutics 26 710-715. (doi:10.1016/ j.pupt.2013.07.003)

Wenzel SE, Robinson CB, Leonard JM \& Panettieri RA Jr 2010 Nebulized dehydroepiandrosterone-3-sulfate improves asthma control in the moderate-to-severe asthma results of a 6-week, randomized, doubleblind, placebo-controlled study. Allergy and Asthma Proceedings $\mathbf{3 1}$ 461-471. (doi:10.2500/aap.2010.31.3384)

Wood DM, Brennan AL, Philips BJ \& Baker EH 2004 Effect of hyperglycaemia on glucose concentration of human nasal secretions. Clinical Science 106 527-533. (doi:10.1042/CS20030333)

Wright RJ 2012 Stress-related programming of autonomic imbalance: role in allergy and asthma. Chemical Immunology and Allergy 98 32-47. (doi:10.1159/000336496)

Wulfsohn NL, Politzer WM \& Henrico JS 1964 Testosterone therapy in bronchial asthma. South African Medical Journal 38 170-172.

Yick CY, Zwinderman AH, Kunst PW, Grunberg K, Mauad T, Fluiter K, Bel EH, Lutter R, Baas F \& Sterk PJ 2013 Glucocorticoid-induced changes in gene expression of airway smooth muscle in patients with asthma. American Journal of Respiratory and Critical Care Medicine 187 1076-1084 (doi:10.1164/rccm.201210-1886OC)

Yim PD, Gallos G, Xu D, Zhang Y \& Emala CW 2011 Novel expression of a functional glycine receptor chloride channel that attenuates contraction in airway smooth muscle. FASEB Journal 25 1706-1717. (doi:10.1096/fj.10-170530)

Zhou S, Potts EN, Cuttitta F, Foster WM \& Sunday ME 2011 Gastrinreleasing peptide blockade as a broad-spectrum anti-inflammatory therapy for asthma. PNAS 108 2100-2105. (doi:10.1073/pnas. 1014792108)

Received in final form 3 June 2014

Accepted 11 June 2014

Accepted Preprint published online 13 June 2014 http://joe.endocrinology-journals.org DOI: $10.1530 / J O E-14-0220$
(C) 2014 Society for Endocrinology Printed in Great Britain
Published by Bioscientifica Ltd. 